\title{
Peningkatan Kehadiran Siswa kelas XI Pemasaran 2 Menggunakan Konseling Perorangan Teknik Eklektik
}

\author{
Aida Mulyani \\ SMK Negeri 2 Padang \\ $\doteq$ e-mail: aida@gmail.com
}

\begin{abstract}
Penelitian ini bernama Penelitian Tindakan Kelas (PTK), dalam Bimbingan dan Konseling (BK) lebih dikenal dengan nama Penelitian Tindakan Bimbingan dan Konseling (PTBK). Penelitian ini dilakukan karena banyak ditemui siswa yang datang terlambat ke sekolah dan kurangnya frekuensi absensi siswa. Oleh sebab itu guru BK mencoba mengurangi keterlambatan ini dengan melakukan layanan konseling perorangan. Untuk lebih memaksimalkan hasil yang diharapkan menggunakan pendekatan konseling perorangan teknik eklektik. Subjek penelitian ini adalah lima orang siswa kelas XI Pemasaran 2 SMKN 2 Padang. Manfaat dari penelitian ini agar siswa yang absen dan terlambat datang ke sekolah dapat berkurang atau bahkan sampai tidak ada lagi siswa yang terlambat datang ke sekolah tiap harinya. Peneliti sebagai konselor dalam memberikan layanan konseling perorangan, dan rekan sejawat sebagai observer. Hasil penelitian menunjukkan bahwa pelaksanaan tindakan layanan dilakukan sebanyak dua siklus, di mana setiap siklus terdiri dari empat tahapan, yakni; (a) perencanaan, (b) pelaksanaan, (c) observasi, dan (d) refleksi. Setelah dilakukan analisis hasil setelah dilakukan pelaksanaan konseling perorangan dengan teknik eklektik, terjadi pengurangan frekuensi ketidakhadiran siswa kelas XI Pemasaran 2. Dari hasil penelitian disarankan kepada guru BK hendaknya mendata dan memantau siswa yang terlambat datang ke sekolah, karena masih ada guru kelas dan guru BK yang bersikap acuh dengan ketidakdisiplinan siswa tersebut.
\end{abstract}

Keyword: kehadiran, konseling perorangan, teknik eklektik

Copyright (C) 2017 IICET (Indonesia) - All Rights Reserved

Indonesian Institute for Counseling, Education and Therapy (IICET)

\section{PENDAHULUAN}

Pelayanan konseling di sekolah merupakan usaha membantu peserta didik dalam pengembangan kehidupan pribadi, sosial, kegiatan belajar serta perencanan dan pengembangan karir (Prayitno \& Erman Amti, 2004). Pelayanan konseling menfasilitasi pengembangan peserta didik secara individual kelompok atau klasikal (Muna, N., Yuwono, W., \& Martiana, E. 2010; Barus, G. 2011; Mega Ralasari, T. 2015) sesuai dengan kebutuhan, potensi, bakat, minat, perkembangan, kondisi serta peluang-peluang yang dimiliki. Pelayanan ini juga membantu mengatasi kelemahan dan hambatan serta masalah yang dihadapi siswa.

Pelayanan konseling diselenggarakan melalui berbagai jenis layanan (Dinartiwi, A. 2010) meliputi layanan orientasi, informasi, penempatan dan penyaluran, penguasaan konten, konseling perorangan, konseling kelompok, konsultasi, dan layanan mediasi. Serta kegiatan pendukung yang mencakup aplikasi instrumentasi, himpunan data, konferensi kasus, kunjungan rumah, tampilan kepustakaan dan alih tangan kasus (Prayitno, 2012).

Salah satu tugas sekolah sebagai lembaga pendidikan adalah menciptakan kesempatan yang seluasluasnya kepada siswa untuk mengembangkan dirinya seoptimal mungkin sesuai dengan situasi lingkungan 
yang ada. Berbagai upaya dilakukan guna meningkatkan prestasi belajar siswa, seperti penyempurnaan kurikulum, melengkapi sarana/pra sarana belajar, peningkatan kompetensi guru dan sebagainya guna menjawab apa yang diamanatkan dalam Undang-Undang Sistem Pendidikan Nasional (UUSP). Namun upaya tersebut tidaklah banyak artinya jika tidak dibarengi dengan semangat/motivasi belajar yang tinggi dari siswa sebagai subjek didik. Berbagai faktor dapat mempengaruhi keberhasilan belajar siswa. Suryabrata (1989) mengelompokan faktor tersebut menjadi dua yaitu faktor internal dan eksternal. Faktor ini ada yang mempengaruhi secara langsung dan ada pula mempengaruhi secara tidak langsung.

Permasalahan yang menyangkut dengan kehadiran siswa di sekolah sudah menjadi hal yang sering ditemui di sekolah. Meskipun sudah ada jadwal kegiatan belajar mengajar yang ditetapkan pihak sekolah, masih banyak di antara siswa yang memiliki frekuensi keterlambatan cukup banyak, termasuk ketidakhadiran siswa. XI Pemasaran 2, salah satu kelas binaan peneliti diindikasi memiliki frekuensi ketidakhadiran dan keterlambatan yang perlu mendapat perhatian khusus untuk dientaskan.

Hamalik (1983) mengemukakan "cara belajar adalah kegiatan belajar yang dilakukan dalam mempelajari sesuatu" artinya kegiatan-kegiatan yang seharusnya dilakukan dalam situasi belajar, kegiatan ini dimaksudkan baik dalam kegiatan tatap muka maupun dalam belajar sendiri. Pada belajar tatap muka inilah diperlukan kehadiran siswa secara kontinyu, agar proses belajar dapat berjalan lancar, dengan demikian dapat memahami pelajaran dengan baik dan pada akhirnya dapat berhasil dalam belajar. Menurut Suryabrata (1989) cara belajar pada pokoknya adalah cara belajar tatap muka.

Begitu pentingnya kehadiran siswa di kelas dalam mengikuti proses belajar mengajar (Kependidikan, D. T., Jenderal, D., Kependidikan, P. M. P. D. T., \& Nasional, D. P. 2008; Daud, F. 2012). Seorang siswa sulit memahami materi pelajaran jika dia tidak ikut berpartisipasi secara aktif di kelas, siswa tidak dapat mengetahui apa manfaat belajar baginya. De Patner dan Mike Hernachi (1992) menjelaskan bahwa dengan mengetahui manfaat belajar dapat meningkatkan minat dan motivasi belajar siswa di kelas. Sehingga kehadiran siswa dapat meningkat secara bersamaan.

Salah satu upaya untuk meningkatkan frekuensi kehadiran dan mengurangi keterlambatan siswa dalam kegiatan belajar mengajar di sekolah dapat dilakukan dengan melaksanakan konseling perorangan (Masruroh, S. 2016; Agus Supriyanto, M. P. 2016; Yayu Hindayah, Y. 2014). Agar terjadi komunikasi dua arah dan efektif antara konselor dan klien, pendekatan konseling eklektik diharapkan mampu memberikan penyelesaian masalah lebih optimal (Utami, M. 2016; Pramita, T. S. 2016).

Konseling eklektik lebih tepat dan sesuai dengan filsafat tujuan bimbingan dan konseling dari pada sikap yang hanya mengandalkan satu pendekatan atau satu dua teori tertentu saja secara optimal, menciptakan hubungan konseling yang hangat, dan permisif. Menurut Roger menjadi tanggung jawab klien sendiri untuk membantu dirinya sendiri. Prinsip yang penting adalah mengupayakan agar dapat menyelesaikan dengan baik. Aliran ini menekankan pentingnya pengembangan potensi dan kemampuan yang secara hakiki ada pada diri setiap individu. Potensi dan kemampuan yang berkembang menjadi penggerak bagi upaya individu untuk mencapai tujuan-tujuan hidupnya.

Berdasarkan permasalahan dan tujuan penelitian, maka penelitian ini termasuk penelitian tindakan bimbingan dan konseling (PTBK). Penelitian tindakan bimbingan dan konseling adalah penelitian tindakan yang dilakukan dengan tujuan untuk meningkatkan program layanan bimbingan dan konseling, sehingga menjadi lebih baik.

Menurut Arikunto (2006) tujuan penelitian tindakan kelas ini adalah untuk memperbaiki persoalan nyata dan praktis dalam peningkatan mutu pembelajaran di kelas yang dialami langsung antara guru dan siswa yang sedang belajar. Action research diselenggarakan dalam rangka mengatasi masalah nyata dalam pembelajaran, berusaha menemukan dasar-dasar dan langkah-langkah perbaikan bagi suatu keadaan dalam proses belajar mengajar.

\section{METODOLOGI}

Bentuk penelitian ini adalah penelitian tindakan layanan (Service Action Research) yaitu tindakan reflektif oleh pelaku tindakan untuk memperbaharui proses pembelajaran melalui layanan konseling 
perorangan dengan teknik eklektik. Maka dalam penelitian ini yang akan diperbaiki adalah rendahnya kehadiran siswa. Penelitan dilakukan pada kelas yang peneliti asuh yaitu kelas XI Pemasaran 2 SMKN 2 Padang. Tindakan yang digunakan untuk memecahkan masalah tersebut adalah konseling perorangan dengan teknik eklektik.

Model penelitian yang peneliti gunakan adalah Model Lewin (dalam Arikunto, 2004) komponennya adalah 1) Perencanaan (Planning), dalam tahap ini peneliti menjelaskan tentang apa, mengapa, kapan, dimana, oleh siapa dan bagaimana tindakan tersebut dilakukan. 2) Pelaksanaan (Actuating). Pelaksanaan yang merupakan implementasi atau penerapan isi rancangan. 3) Pengamatan (observing), kegiatan observasi dilakukan untuk mengamati aktifitas anak dan guru selama proses layanan berlangsung. 4) Perenungan (Reflecting), Merumuskan hal-hal yang belum dan telah dilakukan berdasarkan hasil observasi dan evaluasi.

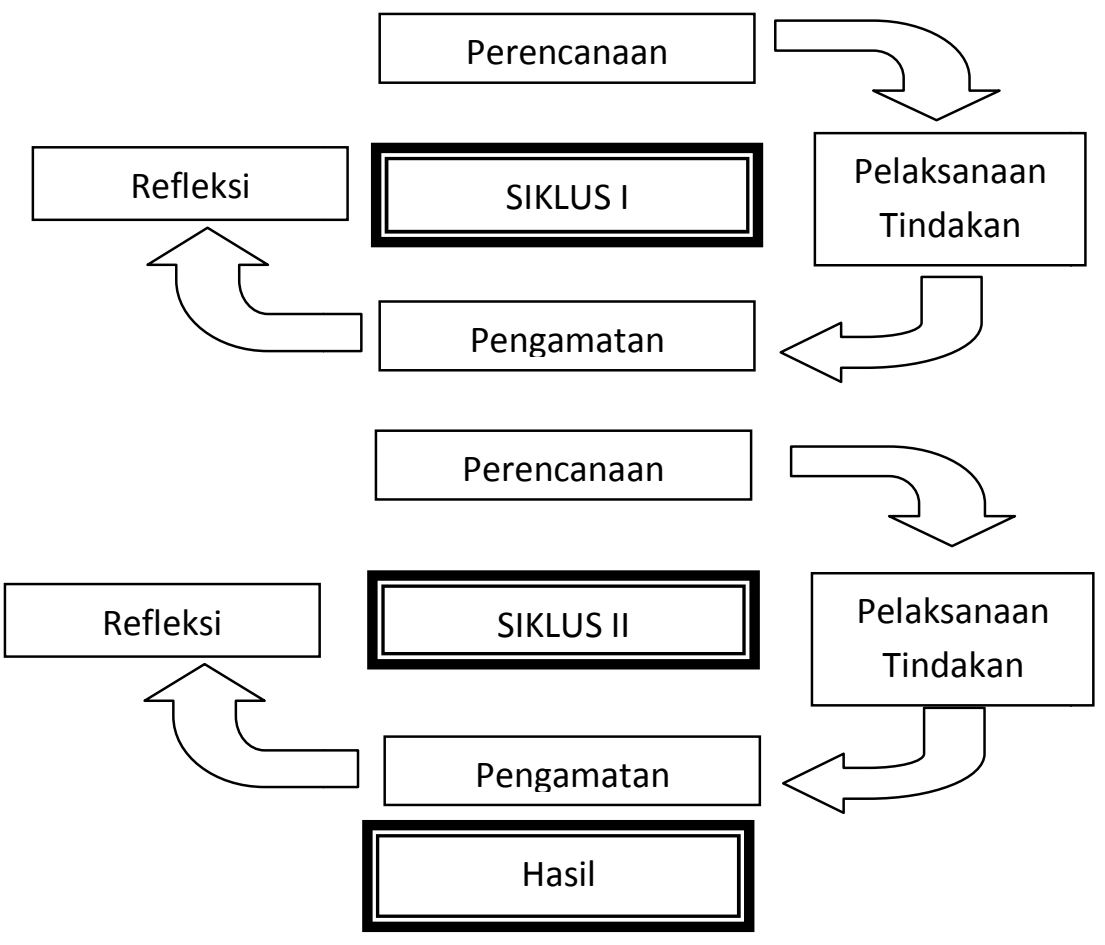

Penelitian tindakan kelas ini dilaksanakan 2 siklus. Setiap pertemuan memerlukan 2 jam pelajaran. Pada setiap siklus terdiri dari empat kegiatan yaitu perencanaan (planning), tindakan (action), pengamatan (observation) dan refleksi (reflection) (Arikunto, 2004). Sebelum penelitian dilaksanakan refleksi awal terlebih dahulu.

Teknik pengolahan data kualitatif dilakukan dengan proses reduksi data, paparan data sampai penyimpulan. Data hasil pengamatan guru sejawat yang berkolaborasi disederhanakan dalam bentuk tabel, dinarasikan dan disimpulkan. Hasil kesimpulan ini dipergunakan untuk memperbaiki penelitian pada siklus berikutnya.

\section{HASIL DAN PEMBAHASAN}

Penelitian dilakukan sebanyak dua siklus, mulai tanggal 27 Juli- 4 Agustus 2015. Berdasarkan data dan pengamatan yang peneliti lakukan selama proses layanan konseling perorangan, pada dasarnya setiap klien sudah memahami bahwa pentingnya kehadiran dalam proses belajar mengajar di sekolah. Klien juga menyadari bahwa datang tepat waktu ke sekolah akan membuat mereka lebih siap untuk menerima pelajaran. Dari komitmen yang disampaikan oleh klien, mereka akan lebih berusaha untuk tidur tidak larut malam, meminta keluarga agar diperhatikan kesiapan klien dalam belajar dan menyetel alarm untuk bangun di pagi harinya. 
Setelah dilakukan konseling perorangan pada siklus I, peneliti mengamati dan memantau kehadiran siswa, baik langsung ke kelas maupun melalui himpunan data absensi siswa. Diketahui setelah siklus I, beberapa klien menunjukkan perubahan dalam frekuensi kehadiran, dan masih ada 1-2 siswa yang belum mencapai target pelayanan. Hal ini bisa disebabkan oleh beberapa permasalahan dalam pelaksanaan siklus I di antaranya: (1) Dalam melaksanakan konseling peroangan dengan teknik eklektik, siswa diminta untuk menceritakan masalahnya secara terbuka, akan tetapi masih ada siswa yang kurang terbuka menceritakan masalahnya, dan (2) Pada penilaian segera (laiseg) masih ada siswa yang belum melaksanakan apa yang telah direncanakannya.

Berdasarkan hasil refleksi di atas, selanjutnya peneliti merancang kegiatan siklus kedua. Pada siklus kedua ini, semua klien yang menjadi subjek penelitian tetap diberikan layanan konseling perorangan teknik eklektik dengan harapan terlaksananya semua komitmen yang telah direncanakan siswa. Di samping itu, target penelitian agar berkurangnya frekuensi keterlambatan dan ketidakhadiran siswa dapat dicapai.

Seteah dilakukan pelayanan konseling perorangan dengan teknik eklektik diberikan kepada siswa. Tujuan penelitian yang disusun pada awalnya sudah menunjukkan angka yang optimal. Dari analisis terhadap kehadiran siswa yang diperoleh melalui absen di kelas, diketahui pada saat siklus 1 masih ada di antara siswa yang memiliki frekuensi ketidakhadiran yang tinggi. Sedangkan pada siklus 2, secara umum keseluruhan siswa telah mengalami peningkatan kehadiran. Sehingga dapat dikatakan telah terjadi perubahan siswa dalam hal kehadiran mengikuti kegiatan belajar di sekolah. Untuk melihat perbandingan hasil antara siklus 1 dan 2 , dapat digambarkan melalui tabel berikut ini.

\begin{tabular}{lllllllllllll}
\hline No & Inisial & \multicolumn{4}{c}{ Siklus 1} & \multicolumn{3}{c}{ Siklus 2} & \multirow{2}{*}{ Ket. } \\
\cline { 3 - 11 } & & S & I & A & T & C & S & I & A & T & C & \\
$\mathbf{1}$ & AP & - & - & 1 & - & 1 & - & - & 1 & - & - & Terjadi \\
$\mathbf{2}$ & AT & - & - & 3 & - & - & - & - & - & 1 & - & peningkatan \\
$\mathbf{3}$ & PA & - & - & 1 & - & - & - & - & - & - & - & \\
$\mathbf{4}$ & RD & - & - & 1 & - & - & - & - & - & - & - & \\
$\mathbf{5}$ & WA & - & - & - & - & - & - & - & - & - & - & \\
\hline
\end{tabular}

Hasil penelitian pada siklus I dan II menunjukkan adanya peningkatan kehadiran siswa dalam belajar. Hal ini menunjukkan hasil yang positif karena dari setiap siklus, jumlah ketidakhadiran siswa terus menunjukkan pengurangan frekuensi. Sehingga dengan hasil yang cenderung meningkat ini, kegiatan layanan konseling perorangan dengan teknik eklektik dihentikan karena telah mencapai hasil yang diharapkan. Selanjutnya akan terus dilakukan pemantauan agar perubahan positif yang ditunjukkan siswa dapat bertahan dan terus ditingkatkan.

\section{SIMPULAN DAN SARAN}

Berdasarkan hasil penelitian tindakan yang telah diberikan melalui konseling perorangan dengan teknik eklektik, menunjukkan adanya peningkatan kehadiran siswa di kelas XI Pemasaran 2. Pada pra siklus, frekuensi ketidakhadiran siswa dapat dikatakan tinggi. Sedangkan dari analisis terhadap kehadiran siswa yang diperoleh melalui absen di kelas, diketahui pada saat siklus 1 masih ada di antara siswa yang memiliki frekuensi ketidakhadiran yang tinggi. Sedangkan pada siklus 2, secara umum keseluruhan siswa telah mengalami peningkatan kehadiran. Sehingga dapat dikatakan telah terjadi perubahan siswa dalam hal kehadiran mengikuti kegiatan belajar di sekolah.

Selanjutnya perlu adanya pembinaan secara berkelanjutan terhadap siswa di kelas ini agar ketidak hadirannya menjadi lebih kecil. Selanjutnya ada kajian yang mendalam dan menyeluruh bagi sekolah dalam menyusun jadwal belajar siswa. Serta, dalam melaksanakan proses belajar mengajar hendaknya guru menggunakan metode mengajar yang bervariasi. 


\section{DAFTAR RUJUKAN}

Agus Supriyanto, M. P. (2016). Buku Panduan Layanan Konseling Individual Pendekatan behavioristik Teknik Shaping untuk Mengatasi Perilaku Terlambat Datang ke Sekolah.

Arikunto, S. (2004). Prosedur Penelitian: Suatu pendekatan praktik. Jakarta: Rineka Cipta.

Barus, G. (2011). Pengembangan Instrumen Asesmen Kebutuhan Perkembangan untuk Penyusunan Kurikulum dan Evaluasi Program BK. Jurnal Penelitian dan Evaluasi Pendidikan, 15(1), 22-46.

Daud, F. (2012). Pengaruh kecerdasan emosional (EQ) dan motivasi belajar terhadap hasil belajar Biologi siswa SMA 3 Negeri Kota Palopo. Jurnal Pendidikan dan Pembelajaran (JPP), 19(2), 243-255.

De Porter, B \& Hernacki, M. (1992). Quantum Learning. Terjemahan oleh Alwiyah Abdur Rahman. New York: Dell Publishing.

Dinartiwi, A. (2010). Persepsi siswa tenyang layanan bimbingan dan konseling di SMK Grafisika Yayasan Lektur Jakarta Selatan.

Hamalik, O. (1993). Metode Mengajar dan Kesulitan Belajar. Bandung: Transito.

Kependidikan, D. T., Jenderal, D., Kependidikan, P. M. P. D. T., \& Nasional, D. P. (2008). Penilaian kinerja guru. Jakarta: Departemen Pendidikan Nasional.

Masruroh, S. (2016). Upaya Peningkatan Kedisiplinan Masuk Kegiatan Belajar Mengajar Melalui Layanan Konseling Individu Pada Siswa Kelas VII H SMP Negeri 4 Surakarta Semester Satu Tahun 2011/2012. Majalah Ilmiah Pembelajaran, (1).

Mega Ralasari, T. (2015). Upaya Pengubahan Perilaku Membolos Siswa melalui Layanan Konseling Kelompok dengan Model CBT. Jurnal Penelitian Tindakan Bimbingan \& Konseling, 1(1).

Muna, N., Yuwono, W., \& Martiana, E. (2010). Sistem Informasi Manajemen Bimbingan Konseling di SMK2 Surabaya Berbasis JSP. EEPIS Final Project.

Pramita, T. S. (2016). Meningkatkan Minat Belajar Siswa melalui Konseling Eklektik dengan Menggunakan Media Superhero pada Siswa Kelas VIII MTS Swasta Darul Ulum Budi Agung Medan TA 2015/2016 (Doctoral Dissertation, Unimed).

Prayitno \& Amti, E. (2004). Dasar-dasar Bimbingan dan Konseling. Jakarta: Rineka Cipta.

Prayitno. (2012). Seri Jenis Layanan dan Kegiatan Pendukung Konseling. Padang: Universitas Negeri Padang.

Sanyata, S. (2012). Teori dan aplikasi pendekatan behavioristik dalam konseling. Jurnal Paradigma, (14), 111.

Suryabrata, S. (1989). Psikologi Belajar. Jakarta: Rajawali Press.

Undang-undang No. 20 tahun 2003 tentang Sistem Pendidikan Nasional.

Utami, M. (2016). Meningkatkan Motivasi Belajar Siswa melalui Konseling Eklektik dengan Menggunakan Media Superhero pada Siswa Kelas VIII DI SMP Negeri 35 Medan TA 2015/2016 (Doctoral dissertation, UNIMED).

Yayu Hindayah, Y. (2014). Bimbingan Konseling Individual dalam Meningkatkan Kedisiplinan Siswa atas Layanan, Hambatan dan Hasil di Satu Atap Cikoneng, Kecamatan Cileunyi, Kabupaten Bandung (Doctoral dissertation, UIN Sunan Gunung Djati Bandung). 